\title{
Reported Result Status Code
}

National Cancer Institute

\section{Source}

National Cancer Institute. Reported Result Status Code. NCI Thesaurus. Code C93653.

A coded value specifying the phase in the lifecycle of the reported result. 